\title{
Diction in Tarlingdut song lyrics by Anom Udin Zaen: Stylistic study
}

\author{
${ }^{1}$ Esi Yulistiana, ${ }^{2}$ Sumarlam, ${ }^{3}$ Soediro Satoto \\ ${ }^{123}$ Linguistics Department, Sebelas Maret University, Indonesia \\ ${ }^{*}$ Corresponding Author \\ Email: esiysutanto@gmail.com
}

\begin{abstract}
Song lyric is a mean to express the writer's message publically. The message itself can be understood through understanding the writer's diction (choice of words). This article concerns to Anom's choices of words on his own 'Tarlingdut' song lyrics. This research aims to reveal Anom's choice of words on his Tarlingdut song lyrics by using stylistic approach. The method used in this research is descriptive qualitative. Inventory report, repetitive and comprehensive reading, and record keeping are techniques used to collect the data. The result shows that Anom's choice of words in his nine song lyrics is aesthetic and unique. The result of the research is expected to make some contribution in understanding Tarlingdut songwriters' choice of words to express their ideas.
\end{abstract}

Keywords: Diction, lyric, tarlingdut, stylistics

$\begin{array}{llll}\text { Received: } & \text { Revised: } & \text { Accepted: } & \text { Published: } \\ \text { 1 June 2018 } & \text { 18 August 2018 } & \text { 28 February 2019 } & \text { 28 February 2019 }\end{array}$

\section{INTRODUCTION}

Language is a means of communication produced by the tongue in the form of symbolic sounds. Words written on song lyrics are the form of the writer's feeling, idea, fantasy, and experience. Stylistics is a branch of linguistics emphasizing on the form of language use, the style of the language, as well as the effects resulted by using certain words in a literary work. Aghagolzade (2012: 3) says that "stylistics is the linguistic analysis of literary texts". Stylistic study shows that the power of language as literature media in generating certain effects since literature work is the reflection of the writer's effort in choosing language.

Tarling songs are literary works originating in Cirebon, West Java, and spreading out to Brebes, Tegal, Pemalang, and the surrounding areas. Tarlingdut needs to be conserved knowing that local songs are influental in shaping the identity of the culture and literature in certain place. One of literary works is song lyrics so that stylistic study is appropriate for analyzing song lyrics. This study chooses Tarlingdut song as it develops without changing its basic characteristics. Tarlingdut needs to be conserved knowing that local songs are influental in shaping the identity of the culture and 
Yulistiana, Sumarlam, Satoto, EduLite: Journal of English Education, Literature, and Culture Vol.4, No.1, February 2019, 55-64 DOI: http://dx.doi.org/10.30659/e.4.1.55-64

literature in certain place. Why Tarling is very influential because Tarling is a genuine product of the culture of Cirebon people so that it can become a medium of communication and education for the community. Tarling's existence is also a form of popular entertainment after being tired of busy activities during the day as fishermen, ranchers, farmers and other jobs. Until now, the existence of tarlingdut is still preserved by the enthusiasts, especially by the people of the aforementioned areas. As the modernization advances, tarlingdut develops without changing its basic characteristics, for which the enthusiasts try to preserve. Due to the uniqeness of tarlingdut, stylistic study needs to be conducted.

Song lyric is a real expression of the songwriters about something they ever felt, seen, listened, and experienced. Specifically, the aesthetics and poeticness level of a song lyric can be affected by the songwriters' style. This research studies Anom's choice of words on his tarlingdut songs. Based on the choice of words, the uniqeness of the lyrics and the message of the songwriter can be seen; hence, the fans can be more interested in listening to tarlingdut songs. The reason underlying the researcher to choose Anom's songs is that the diction is aesthethic. It is proven by the sucess of his songs to charm tarlingdut fans.

Diction is a manner to choose apt words to express something. Diction is one of the most important aspect in literature and the writing of song lyric since aesthetic words can produce certain effects towards the listeners; and eventually, the message of the songwriter can be conveyed. Pradopo (2012: 54) states that "poets have to express their feeling and ideas as accurate as possible as per to what their hearts want by realizing it onto a certain work". Therefore, the choice of words has to be accurate. Based on his theory, Anom's choice of words is a means to express his feeling and ideas and to convey certain message.

Based on the expounding of background above, the problems of the research can be formulated as follows: how Anom's choice of words is implemented on his Tarlingdut songs? The purpose of this research is to describe Anom's choice of words on his Tarlingdut song lyrics. Therefore, this research is entitled "Diction in Tarlingdut Song Lyrics by Anom Udin Zaen".

\section{Stylistics}

Stylistics is a discipline focusing on style. According to Wellek and Warren (in Sutejo, 2010: 2), stylistics includes every techniques used to study certain expressions, and it covers broader areas instead of literature and rhetorics. Meanwhile, Satoto (1995: 4) defines stylistics as a linguistic field which includes theory and methodology to study and analyze a literary work. Stylistics is included as extended. Extended is a view that covers studies related to language as the main aspect and accepts linguistic theory as relevant matters (Sutejo, 2010: 2).

Naturally, style is a linguistic means used by poets in their works. In other words, it is agreed that style is used as a rhetorical means to express aesthetics coming from the deepest emotion of the poets; and as a way to express feeling and idea to the world Aminudin (in Sutejo, 2010: 3). Nurgiyantoro (2014: 75) adds that stylistic study is not merely about literature alone but it can also be used on the other linguistic matters. Further, 
Nurgiyantoro (2015: 3) explains that stylistic study is a study focusing on the use of language in certain interaction, variation, and context. Style is also defined as a bunch of author's style and characteristics tied into one on a certain literary work. For example, by reading Chairil Anwar's poem, we know the distinguishable difference between his characteristics and those written by W.S Rendra.

\section{Denotative and connotative}

Denotative meaning is the general (actual) meaning or the real meaning contained in the word. For example, the word " mangan (eating)" means an activity in putting something in the mouth, chewing with teeth and then swallowing it. Whereas the connotative word is not the actual meaning, it is the metaphoric meaning or additional meaning. For example, the word "putih (white)" can mean "holy / clean / sincere" but it can also mean "surrender or innocence".

\section{Diction}

Diction is derived from Latin word dicerce, dictum meaning to say. Diction means choice of words or words arrangement in an utterance or writing (Scoot in Wisnu, 2003:64). Choice of words or diction is an ability to differentiate meaning, to convey meaning, and an ability to compose apt structure suitable for the context and audiences. Writers have to choose words thoroughly since the words which are going to be poured down have to be balanced. It means that the writers have to consider the words meaning, sound composition in rhyme, and rhythm, as well as the paradigmatic and syntaxmatic relationship. Besides choosing apt words, the writers have to consider the words arragement and the words power or so called 'magical sense'. Whether or not the meaningful words are shifted with new meanings and meaningless words imbued with meanings is fully on the writers' hands (Waluyo in Praja, 1995: 11).

\section{Tarling}

Tarling is a famous traditional art originating in Cirebon and Indramayu. The term tarling itself comes from the combination of the dominant musical intruments used in it, gitar (guitar) and suling (flute). Besides those musical instruments, tarling also involves some percussion like saron, kempul, and gong. This description alone already shows that tarling is included in the genre of music. However, in a deeper sense, tarling is not pure about music, instead it also contains literary aspects (Supriatin, 2012:93-94). In other words, tarling as a type of music also contains literary art that is able to present distinctiveness. Tarling music has its own characteristics; First, Tarling music was originally born and developed in the Cirebon community. Second, the songs being performed still use the typical Cirebon language and are different from the Javanese language typical of Solo- Jogjakarta. Third, the tarling songs that are sung contain various magical and spiritual elements for the audience. Fourth, tarling music even with different languages, but its distinctiveness is able to captivate the hearts of the audience along the Pantura route (from Cirebon, Brebes, Tegal, Pemalang to Pekalongan. 
Yulistiana, Sumarlam, Satoto, EduLite: Journal of English Education, Literature, and Culture Vol.4, No.1, February 2019, 55-64 DOI: http://dx.doi.org/10.30659/e.4.1.55-64

\section{METHOD}

The place of research is not related to one place because the object being studied is in the form of text, namely the lyrics of seven songs by Anom Udin Zaen, namely "nambang dawa, kawin paksa, kebayang, pinter kodek, bagja, gandrung dan wis cukup dosae".

This research includes the type of qualitative descriptive research. Kirk and Miller (in Moleong 2007) explain that qualitative research is a particular tradition in social science that is fundamentally dependent on observing humans in their own region and dealing with these people in their language and terminology".

Data sources used in this study are documents. The document used is the lyrics of Tarlingdut's songs by Anom Udin Zaen with Cirebon dialect Javanese. While the data collection technique used in this study is the note taking technique and documentation. Documents can be in the form of personal notes, diaries, work reports, work records, video recordings and photos connected with tarling by Anom Udin Zaen. According to Arikunto (1993: 202) documentation techniques are methods for disclosing written data about things or variables, in the form of notes, books, newspapers, magazines and others. This is used to obtain information that was not obtained at the time of the interview. The document used "by Anom Udin Zaen in seven Tarling song lyrics in order to obtain affective information. Afterward, according to Sudaryanto (1993: 133) the referral technique is the provision of data carried out by listening to language usage data. In accordance with this view (Mahsun, 2005: 242), the referral method is the method used to obtain data by listening to the use of language. After the data is needed, then the data is examined by the researcher examining the diction that contains the lyrics of the songs by Anom Udin Zaen with the aim to determine the extent to which the choice of words or diction chosen by the author can affect the readers or audiences. As for the note-taking technique, according to Kesuma (2007: 45) it is stated that the note-taking technique is the technique of capturing data by recording the results of listening to data on the data card.

In obtaining the data, the researcher in the study used triangulation. The triangulation used is theory triangulation, which is by research on the same topic using different theories in analyzing data. Whereas the data analysis technique used in this study uses flow analysis, which includes three components, namely: (1) data reduction; (2) data presentation; (3) drawing conclusions. The following is the explanation: (1) Data reductions, in this step the data obtained is recorded in detailed descriptions. From the variety of data that has been recorded, then simplification of data is carried out. Where the data chosen by the researcher are only data relating to the problem to be analyzed, namely the diction of the lyrics of Tarlingdut songs by Anom Udin Zaen; (2) Data presentation, in this step the data that has been determined is then arranged in detail so that it is easy to understand. The composition of the data is then analyzed so that a variety of descriptions are obtained regarding diction or choice of words; (3) Drawing conclusions (verification) is the conclusion stage about the results from the beginning of the study. After getting conclusions, verification is still needed (re-research on the truth of the data obtained) so that the results obtained are truly valid and can be justified. 
Research Procedure conducted by researchers consists of several stages, namely as follows: (1) Data collection, in this stage the researcher collects data in the form of quotations that show diction contained in the Tarlingdut song lyrics by Anom Udin Zaen; (2) Selection of data, variety of data that has been obtained or collected, then selected (selection) which will be analyzed and included in diction categories; (3) analyzing data contained in table; (4) Concluding data, this process is the final stage of a series of research processes. It is an effort to convey data that have been analyzed, formulated and drawn for the conclusions.

\section{RESULTS AND DISCUSSION}

Choice of words (diction) in Anom's Tarlingdut song lyrics are varies and rich. In a deeper sense, there are several songwriters that use words with connotative meanings either in general or personal which are conciously chosen in order to imbue the sense of freshness, aesthics, uniqeness, and expresiveness. Anom's characteristics in choosing words on his Tarlingdut song lyrics can be expounded into four parts: 1) denotative and connotative words, 2) concrete and abstract words, 3) personal diction, 4) wangsalan.

\section{Denotative and connotative meaning Denotative meaning}

Denotative words according to Altenbernd (in Pradopo, 2014: 59) are dictionary words which refer to something that are given by that name. In other words, denotative meaning is the real meaning without any additional meaning. The followings are denotative words found on song lyric entitled "Pinter Kodek": Adate wong lanang yen ngomong akeh kebuang//. The denotative words are "buang" and "kosong". The word "buang" has explicit meanings 'throw away', 'remove', 'discard something unecessary from the hands'. The word "buang" in lyric "Adate wong lanang yen ngomong akeh kebuang" portrays the feeling of a wife who dislikes her husband due to men's trait that often talk unecessarily.

Another denotative meaning is found in the line "Yen mangan rasane ra ngeli/ on the word "mangan" which means eating, putting food into the mouth and swallowing it.

\section{Connotative meaning}

Connotation or connotative meaning as stated by Leech (in Al Ma'ruf, 2009: 53) is a communicative value of a certain expression based on what it refers; it is beyond its actual conceptual meaning. Accordingly, connotative meaning is a phrase or a word having implied meaning since its application in a sentence deviates from its literal meaning. This is connotative word found in song lyrics "Nambang Dawa": "Alias nambang dawa/". The connotative word is found in a word "nambang dawa" that means "overextending a particular matter or an endless and uncertain fate'. The word "nambang" means 'rope' and the word "dawa" means long'. The phrase "nambang-dawa" is selected to emphasize the songwriter's intention about a sad and mystified wife as there is no certainty regarding to the relation with her husband who leaves her without words. The song lyrics "nambang dawa" is included as a connotative meaning 
Yulistiana, Sumarlam, Satoto, EduLite: Journal of English Education, Literature, and Culture Vol.4, No.1, February 2019, 55-64 DOI: http://dx.doi.org/10.30659/e.4.1.55-64

since it shows implied meaning. The use of connotative word is also found in Tarling songs lyrics entitled "Pinter Kodek" which is "Pinter kodek": "Pantes diarani wong lanang sing pinter kodek/Yen bengi begadang esuk njaluk lawang/". The meaning of "pinter kodek" is unfair; cunning. It is the condition when someone always asks for something without giving. "Pinter kodek" is a term used for someone who wants to be happy but he/she ignores others' happiness (take advantages for him/herself and disadvantage others).

\section{Concrete words and abstract words Concrete words}

Concrete words are words that refer to something which can be directly understood by one or more human's five senses. Concrete words are able to be felt, seen, touched, heard, or smelt. As stated by Kunjana Rahadi (2009: 67), concrete words refer to object that can be chosen, heard, felt, touched, and smelt. According to Soedjito and Djoko Saryono (2011: 2), concrete words indicate words which refer to object that can be seen, heard, felt, or smelt. Some examples of concrete words are: beautiful, water, fragrance, warm, sound, desk, chair, house, cold, learn, work, money, car, and rice field. The use of concrete words in song lyrics Tarlingdut are as follows: "Yen bengi begadang esuk njaluk lawang/. The use of concrete word in song lyrics "Pinter kodek" is the word "lawang" that denotes "door" as an entrance and exit. The word "lawang" is chosen to give more details and to emphasize the songwriter's intention. This part of the song tells about a husband that wants to have self-enjoyment; while he comes back home after having fun at night, he asks his wife to open the door.

\section{Abstract words}

Abstract words are words referring to object that cannot be grasped by the five senses. In other words, abstract words require us to have deeper understanding since it is not explicit. It concerns on the ideas and concept.

Abstract words according to Sabari (in Hardianto, 2017: 91) are those which are related to concepts. Furthermore, Rahadi (2009: 68) states that abstract words are that refer to concepts or ideas. Abstract words are usually used to express complex ideas. Commonly, abstract words are in the form of affixes. The examples of abstract words are: heroism, kindness, sublime, trust, anger, happiness, justice, gift, rich, poor, art, craft, democracy, prosperity, and peace. The use of abstract word in Tarlingdut composed by Anom Udin Zaen entitled "Wis cukup dosae (stop committing sin)" is: "Percuma moal bakal tek ampura/ Tek sangka setia tek sangka bahagia/". The use of abstract word "bahagia" (happy) is used to show the feeling of contentment and peaceful (free from burden). "Rasa murag terus mata mendelik/ Saban dina sewot langka lirene/. The word "murag (anger)" and "sewot (angry)" found in a song entitled "bagdja" is a concept that cannot be sensed. Thus, those words are considered as abstract words. The word "sewot" means irritated, cranky, or angry. It is use to show terrible emotion.

\section{Personal diction}

Personal diction is a specific diction that is intentionally created and used by the author (poet) because of several factors such as ethnicity, culture, religion, 
education, viewpoint, and so on. Anom Udin Zaen frequently uses unique and beautiful diction to show his personal expression, idea, and condition. Anom Udin Zaen's diction is affected by his culture, religion, and feeling. When the songwriter feels happy, specific diction "Pinter kodek" is found in a song "Nambang Dawa". Meanwhile, Anom's diction related to his religion is found in a song entitled "Kawin Paksa" in a lyric "Sabar tek trima bokat suratan/Takdir Kang Kuwasa/".

\section{Archaic affixation}

Affixation including "ater-ater (prefix), panambang (suffix), and imbuhan bebarengan (confix) causes the language used in literary work unique, remarkable, and beautiful. Below is archaic affixation used by Anom to make words, phrases, and sentences to be more aesthetic.

\section{Ater-ater (prefix)}

"Paite getire wis tek rasakna kabeh/ Percuma moal bakal tek ampura/ Tek sangka setia tek sangka bahagia/ Sabar tek trima bokat suratan/ Takdir Kang Kuwasa/ (Song lyrics "kawin paksa"). The common prefix used in Cirebon dialect indicates passive form characterized by prefix / tak /-- / tek- / for a first person such as "takbandhem" or "tekbandhem (I throw)" or sometimes "dibandhem kula" with the word "kula" that means "I". This example is found in song lyrics "Wis cukup dosae" and "kawin paksa". "Sedina sun kalayang/ Seminggu sun kelayu/ Sewulan sun kelingan/ Setahun sun keyungyung/" is a Tarling lyrics in a song entitled "kebayang". In this song, prefix $\{s e-/ s a-\}$ is combined with roots [dina], [minggu], [wulan], dan [taun]. Thus, they become [sedina], [seminggu], [sewulan] and [setahun]. "Lara ning ati ditinggal laki/ Rasane sedih tanpa permisi/ Diputus bli dipegat bli/ Batik kesiksa digawe lara/". In the lyrics of a song "nambang dawa", prefix $\{d i-\}$ is combined with roots [tinggal], [putus], [pegat], and [gawe]. However, the use of prefix does not create a certain phonemic change since the words become [ditinggal], [diputus], [dipegat], and [digawe].

"Adate wong lanang yen ngomong akeh kebuang/". In the lyrics of a song "pinter kodek", there is prefix \{ke-\} which is combined with root [buang] so that it turns out to be [kebuang]. Adate wong lanang yen ngomong akeh kebuang/".

\section{Panambang (suffix)}

Suffix in Javanese, especially in Cirebon-Tegal dialect, is in the form of $\{-a\}$, $\{-$ an\}, $\{-\mathrm{e}\},\{-\mathrm{i}\},\{-\mathrm{en}\},\{-\mathrm{na}\}$, dan $\{-$ aken $\}$ which are combined with particular morphemes. The use of suffix found in tarling song lyrics entitled "pinter kodek" written by Anom Udin Zaen is "Padahal sih salah nanging jawabe bisaan/". Suffix $\{-a n\}$ is combined with morpheme [bisa] so that it becomes [bisaan].

In a song "Kebayang", suffix $\{-a n\}$ is found: "Penasaran watir demenan/"; "Kebayang-bayang ning pikiran"; and "Cemburuan kanggo pawitan/ Penasaran watir demenan/ Pancen rata-rata wong lanang pinter alesan/Padahal sih salah nanging jawabe bisaan/". Suffix \{-an\} is combined with roots, [demen], [pikir], [cemburu] and [bisa]. The addition of the suffix forms the words [demenan], [pikiran], [cemburuan], and [bisaan]. In a song 
Yulistiana, Sumarlam, Satoto, EduLite: Journal of English Education, Literature, and Culture Vol.4, No.1, February 2019, 55-64 DOI: http://dx.doi.org/10.30659/e.4.1.55-64

"kawin paksa", there is a use of suffix $\{-\mathrm{e}\}$ : "Dasar wong tuwa pancene tega" and "Yen dipikir-pikir wong lanang enake dewek/." In this song, suffix \{-e\} forms the words [pancene] and [enake]. Another suffix $\{-\mathrm{e}\}$ is used in a song bagja": "Bagja temen isun iki uripe/Due laki keras pisan wateke/Kadangkadang langka pisan kosonge/Saban dina sewot langka lirene/Ana bae bahan lantarane/Memang susah angel diladenane/". In "bagja" song lyrics, suffix $\{\mathrm{e}\}$ is attached in [urip], [watek], [kosong], [liren], [lantaran], and [laden]. The words then turn into [uripe], [wateke], [kosonge], [lirene], [lantarane] and [diladenane]. Besides there is suffix $\{-\mathrm{i}\}$ in a song "pinter kodek "Wong wadon nakoni jawabe karo nyewoti". Suffix $\{-\mathrm{i}\}$ is added on the morpheme [takon] "asking" so that it becomes [nakoni].

\section{Confix (the use of both prefix and suffix)}

The example of confixes in tarlingdut are $\{\mathrm{N}-/-\mathrm{i}\}$, $\{\mathrm{ke}-/-\mathrm{an}\},\{\mathrm{pe}-/-\mathrm{an}\}$ and $\{\mathrm{peN}-$ /-an\}. The formation process can be observed as follows: "Setibane wong demen kelingan/". In this lyrics, confix $\{k e-/-a n\}$ is found in a song "gandrung". The confix is combined with \{eling\} so that it becomes [kelingan]. Besides confix $\{\mathrm{ke}-/-\mathrm{an}\}$ is also found in another song entitled "kebayang": "Kelingan karo pujaan ati/". In this song the confix is also combined with \{eling\} so that word [kelingan] that means "remember" is formed.

\section{Wangsalan}

Wangsalan is a spoken tradition that still exists in Pantura, especially in Indramayu and Cirebon. Based on etymology, Cirebon Wangsalan comes from repetitive word "wangsal-wangsul (answer, come home)". Moreover, it is a series of sentences that refer to single meaning. In a modern terminology, it is often called as rhyming slang. It is similar with badhekan riddle such as misalnya kembang putih mlipir gunung that means "cloud" or gelang alit mungging jriji that means "ring" (Supriatin, 2012: 94). In addition, wangsalan is a kind of sentence that conveys meaning by using similar words (rhyming slang). For example: "Balung jagal (bagal" that means "dugal" and "toya mijil saking langit (udan) are combined into edan (crazy). Cirebon Wangsalan that is found in Tarlingdut song lyrics entitled "nambang dawa" composed by Anom Udin Zaen is "nambang dawa" which means "ngulur-ngulur" or overextending a particular matter without any clarity. Furthermore, the work of Anom Udin Zaen in a song entitled "pinter kodek" was also found in Wangsalan, namely "Pantes diarani wong lanang sing "pinter kodek" (it is appropriate to consider a smart man to pry / rummage) " who has the meaning "pinter ( clever) and "codec (prying / trying to remove small items with nails / other objects)".

The word "pinter kodek" contains wangsalan which is more precisely means the term for people who cheat, want to be nice or cunning. The meaning of the extent, want to win alone, want to be happy alone, like rats abandoning the sinking ship or being a fair weather friend. Wangsalan in the tarling song lyrics was also found in the song lyrics titled "Gandrung (falling in love)" which is "Kaliang kabur kenang kanginan, setibane wong demen kelingan/". More clearly it has the meaning "the fall of people falling in love is always remembered / always being haunted by his sweetheart". With some examples found in the work of Anom Udin Zaen proving that Tarling's lyrics are not only intended to provide aesthetic effects in terms of folk 
entertainment but also contain educational values for the people who love them. This is in agreement with the opinion of Salim (2015: 67), namely Tarling music since its development up to the present, has several functions, one of which is as a medium of education. Educating messages in the Tarling show were not only expressed through dialogue in the form of prose language, but also expressed through dialects in the form of poetic language.

\section{CONCLUSION}

Based on the research findings and data analysis, it can be concluded that the diction used in tarlingdut song lyrics composed by Anom involves denotation, connotation, common words, terminology, abstract words, and concrete words. Personal diction, wangsalan, and archaic affixation are able to covey the songwriter' message clearly, appropriately, and exquisitely. Therefore, it eases the listeners to enjoy the song. Based on the stylistic study of the lyrics of the tarlingdut songs by Anom Udin Zaen the conclusions can be stated as follows. First, diction (the word style) used in the lyrics of the tarling songs by Anom Udin Zaen relates to connotations and denotations, general meanings and special meanings, concrete words and abstract words, personal diction, wangsalan and archaic affixations.

Regarding the diction, the most dominant diction in Anom Udin Zaen's tarlingdut song was not found. This can be seen from the results obtained, namely for the denotation found 3 data, namely (the words " kebuang, kosonge, and lawang"), while for the connotative words found 3 data, namely "nambang dawa, pinter kodek dan kaliang kabur kenang kanginan". 6 Second, the choice of words or diction used by Anom Udin Zaen is an effort of the author in choosing which words to choose to reach an idea and forming a distinctive style of expression that is appropriate so as to enlighten the readers or listeners.

\section{REFERENCES}

Aghagplzade, Ferdows. (2012). Stylistics and Linguistic Variations in Forough Farrokhzad.s Poems. Journal of Language Teaching and Research, Vol. 3, No. 5, pp. 930-939, September 2012.

Agemo, Oluwatosin Stella. (2011). A Stylistics analysis of some selected poems by Wole Soyinka. (Undergraduate thesis, University of Ilorin, 201). Diunduh dari http://www. unilorin.edu.ng/studproj/arts/0715CD026.pdf

Al -Ma'ruf, Ali Imron. (2009). Stilistika: Teori, Metode, dan Aplikasi Pengkajian Estetika Bahasa. Solo: CakraBooks Solo.

Arikunto, Suharsimi. (1993). Prosedur Penelitian: Suatu Pendekatan Prakris. Jakarta: PT. Rineka Cipta.

Asis, Abdul. (2010). Mengungkapkan penggunaan diksi lirik lagu Bugis ciptaan Jauzi Saleh: Kajian Stilistika. Kandai. Vol.6, 101-110. No. 1, Mei 2010. 
Yulistiana, Sumarlam, Satoto, EduLite: Journal of English Education, Literature, and Culture Vol.4, No.1, February 2019, 55-64 DOI: http://dx.doi.org/10.30659/e.4.1.55-64

Hardianto, Musa. (2017). Diksi Dan Gaya Bahasa Pada Naskah Pidato Presiden Soekarno. Fonema. Vol. 4. No. 2. Desember 2017.

Kesuma, Tri Mastoyo Jati. (2007). Pengantar (Metode) Penelitian Bahasa. Yogyakarta: Carasvatibooks.

Moleong, Lexy J. (2007). Metodologi Penelitian Kualitatif. Bandung: Remaja Rosda Karya.

M.S, Mahsun. (2005). Metode Penelitian Bahasa: Tahapan Strategi, Metode dan Tekniknya (Edisi Revisi). Jakarta: PT. RajaGrafindo Persada.

Munir, Saiful, dkk. (2013). Diksi dan Majas dalam Kumpulan Puisi Nyanyian Dalam Kelam Karya Sutikno W.S: Kajian Stilistika. Jurnal Sastra Indonesia 2 . Vol 3, No.1, November 2013. ISSN 2252-6315.

Nurgiyantoro, Burhan. (2014). Stilistika. Yogyakarta: Gadjah Mada University Press.

Nurgiyantoro, Burhan. (2015). Stilistika Kultural (Cultural Stylistica). Jurnal Widyaparwa. Vol 43. No. 1.

Pradopo, Rachmad Djoko. (2014). Pengkajian Puisi. Yogyakarta: Gadjah Mada University Press.

Rahadi, Kunjana. (2009). Penyuntingan Bahasa Indonesia untuk KarangMengarang. Jakarta: Erlangga.

Salim. (2015). Perkembangan dan Eksistensi Musik Tarling Cirebon. Catharsis: Journal of Arts Education, Vol. 4, No. 1, 65-70, Agustus 2015.

Soedjito dan Saryono, Djoko. (2011). Seri Terampil Menulis: Kosa Kata Dalam Bahasa Indonesia. Malang: Aditya Media Publishing.

Supriatin, Yeni Mulyani. (2012). Teks Tarling: Representasi Sastra Liminitas (Analisis Fungsi Dan Nilai-Nilai). Jurnal Metasastra, Vol. 5. No. 1.

Sutejo. (2010). Stilistika Teori, Aplikasi \& Alternatif Pembelajarannya. Yogyakarta: Pustaka Felicha.

Rahadi, Kunjana. (2009). Penyuntingan Bahasa Indonesia Untuk KarangMengarang. Jakarta: Erlangga.

Salim. (2015). Perkembangan dan Eksistensi Musik Tarling Cirebon. Catharsis: Journal of Arts Education, Vol. 4, No. 1, 65-70, Agustus 2015. 